\title{
Ability to Synthesize Extracellular Metabolites of Rice Endophytic Bacteria Before and After $g f p$ Gene Transformation
}

\author{
Ali Ikhwan \\ Agrotechnology Department \\ University of Muhammadiyah Malang \\ Malang, Indonesia \\ aliikhwan64@gmail.com
}

\begin{abstract}
The purpose of this research was to investigate the ability of rice endophytic bacteria to synthesize extracellular metabolites before and after $g f p$ (Green Fluorescent Protein) gene transformation. These bacteria were grown in liquid media M63+2mM Tryptophan for 3 days and the supernatants were extracted with absolute methanol 1:1 (v/v). The extractants were then analysed with Gas Chromatography-Mass Spectrophotometry (GC-MS). The GC-MS result showed that all isolates that were tested be it the control (without transformation) and the mutants (transformed) were able to synthesize growth hormones with different composition patterns, namely Indole 3 Butryric Acid (IBA), Indole Acetic Acid (IAA), Kinentin, Cis Zeatin, Zeatin, Benzylaminopurine, Giberellic Acid (GA3, GA1) as well as Zeatin Riboside. Furthermore, the isolates also synthesised osmoprotectants, namely Glycine, Proline, Arabinose, Thiamine, and Trehalose with different composition patterns as well.
\end{abstract}

\section{Keywords-Endophytic Bacteria, Extracellular, Flourescent, Metabolite}

\section{INTRODUCTION}

Endophytic bacteria are bacteria that live in the plant tissue and form a symbiotic relationship with the host plants [1]. Malfanova [2] stated that endophytic bacteria that colonized the plant tissue obtain their host plant's nutrition and in return give phytohormone to the host plants ${ }^{2}$. Some endophytic bacteria are able to synthesize compounds that are beneficial to the plants such as antimicrobial compounds, degradation enzyme for cell wall and growth regulators auxin, cytokinin and ethylene [3]. Hallman, and Berg [4] stated that the endophytic bacteria live in the plant tissue that is healthy and play a role in stimulating plant growth by producing growth regulatory compounds such as IAA (Indole Acetic Acid), GA3 (Gibberellic Acid), dan Cytokinine 4 . Moreover, the endophytic bacteria are able to maintain and improve the soil fertility by providing $\mathrm{P}$ and fixating $\mathrm{N}_{2}$ [5].

Secondary metabolites that are produced by the microbes are beneficial for the growth and development of the plants. Growth regulators that are produced can increase the root length, number of root branches and root hairs, dry mass of root as well as the length of the stem in some plants. The fast root growth is beneficial for young plants to absorb water and nutrients from the environment. This is advantageous especially for plants that grow in dry area where scarcity of water is the main growth inhibitor. Antimicrobials and degradation enzyme for cell wall that are produced are able to

\author{
Fywit Eka Fransiska \\ Agrotechnology Department \\ University of Muhammadiyah Malang \\ Malang, Indonesia
}

help resist pathogen attack that may cause diseases in plants [4].

Rice endophytic bacteria isolates that are able to synthesize phytohormone and osmoprotectants are obtained from previous experiment result. These bacteria are also already genetically marked with gene $g f p$ (green flourescent protein) to examine their distribution in the plant tissue. The previous experiment did not study the effect of the transformation with gene $g f p$ to the change in the bacteria's ability to synthesize growth hormones and osmoprotectatns extracellularly. Therefore, this experiment aims to study further the bacteria's ability to synthesize growth hormone and osmoprotectants before and after transformation of gene gfp.

\section{METHODS}

\section{A. Date and Place of Research}

This research was conducted in Biotechnology Laboratory of Universitas Muhammadiyah Malang from August 3, to October 29, 2017.

\section{B. Materials}

The materials that were used comprised untransformed endophytic bacteria IM-3 (control) and transformed IM-3 with $g f p$ (mutant IM-3 $+g f p$ ) and mineral media M63 $+2 \mathrm{mM}$ Tryptophan $+0.5 \mathrm{M} \mathrm{NaCl}$. The composition of the $\mathrm{M} 63$ media was $\mathrm{KH}_{2} \mathrm{PO}_{4} 100 \mathrm{mM}$, KOH $75 \mathrm{mM},\left(\mathrm{NH}_{4}\right) 2 \mathrm{SO}_{4} 15 \mathrm{mM}$, $\mathrm{MgSO}_{4}$ 0,16 mM, $\mathrm{FeSO}_{4} 3.9 \mu \mathrm{M}$ and D-glukosa $10 \mathrm{mM}$ [6].

\section{Growth Analysis}

Isolates IM-3 (control) and mutan IM-3 $+g f p$ were grown on the media $\mathrm{M} 63+2 \mathrm{mM}$ triptopan $+0,5 \mathrm{M} \mathrm{NaCl}$, at a temperature of $36{ }^{\circ} \mathrm{C}$ and shake of $125 \mathrm{rpm}$ overnight. The bacteria growth was observed every 2 hours by spectrophotometry, with the wavelength $\lambda 420 \mathrm{~nm}$.

\section{Extracellular Metabolite Preparation}

Cell culture was harvested, and the supernatant obtained was extracted with absolute ethanol 1:1 (v/v), and concentrated with cold ethanol to 50 times. The extracellular metabolite extract was then analysed with Gas Chromatograph Mass Spectrometer (GC- MS) [7].

\section{E. Extracellular Metabolite Analysis}

The metabolyte was analyzed using GC-MS type Shimadzhu QP 2010 SE, with semi-polar column RXi-5MS, 
length of $30 \mathrm{~m}$ and inner diameter (ID) $0.25 \mathrm{~mm}$, heliumcarrying gas with the flow rate of $0.5 \mathrm{ml} / \mathrm{min}$, and pressure of $27.4 \mathrm{kPa}$. The initial temperature of the GC-MS was $120^{\circ} \mathrm{C}$ and 5 minute after injection, it was raised at a rate of $5^{\circ} \mathrm{C} / \mathrm{min}$ until it reached $320{ }^{\circ} \mathrm{C}$ and the sample was inserted using a microinjector with a volume of 1-2 ul [8].

\section{RESULTS AND DISCUSSION}

\section{A. Analysis of Bacteria Growth on Media M63 $+2 m M$ Tryptophan $+0.5 \mathrm{M} \mathrm{NaCl}$}

The result of the analysis of the endophytic bacteria on media $\mathrm{M} 63+2 \mathrm{mM}$ Tryptophan $+0.5 \mathrm{M} \mathrm{NaCl}$ shows that there was a difference in the growth pattern between the control (untransformed) and the mutant. The initial bacteria growth of the control was faster than the mutant bacteria, but the mutant bacteria was able to achieve higher growth. Accordin to Allison and Sattenstall [9], insertion of foreign genes to the host cell would increase the size of the DNA genome of the cell which affects the metabolism and the cell growth.

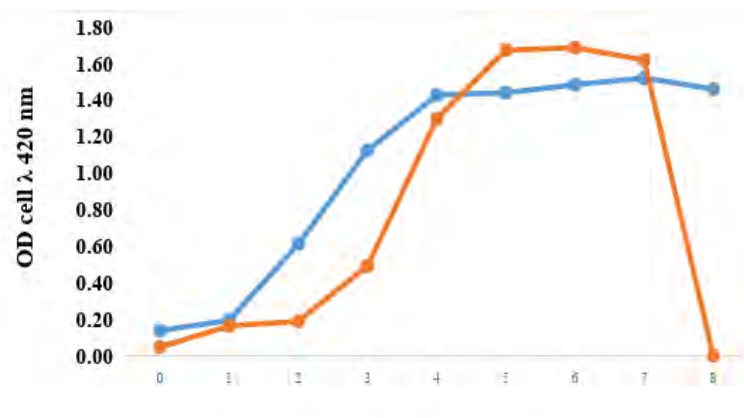

observation time (hours)

Figure 1. The growth of isolates: - IM-3 control, and mutant IM- $3+g f p$ on the media M63 $+2 \mathrm{mM}$ Tryptophan + $0.5 \mathrm{M} \mathrm{NaCl}$

\section{B. Analysis of Extracellular Metabolites: Growth Hormone}

The result of the analysis of extracellular metabolites using GC-MS is obtained from 9 metabolites that lead to growth hormone (Figure 2). The GC-MS analysis result also shows there was an increase in the synthesis of the extracellular growth hormone metabolites in the mutant bacteria compared to the control (untransformed). This indicates that the gene $g f p$ that was inserted into the genome increased the metabolism of the cell in the synthesis of growth hormone and the cell has the potential to be a organic fertilizer agent [10]. According to Cardinale et al [11], foreign genetic insertion into the genome of an organism (bacteria) affects the metabolic system of the cell by rearranging the metabolism, increasing the synthesis of some metabolites and decreasing the synthesis of other metabolites ${ }^{10}$. Furthermore, the result of the analysis shows that Giberilic Acid-3 (GA3) was synthesized with the highest percentage and Benzylaminopurine with the lowest percentage. This shows that GA3 is a growth hormone that was most efficiently synthesized in the osmotic pressure $\mathrm{NaCl}$ condition [12].

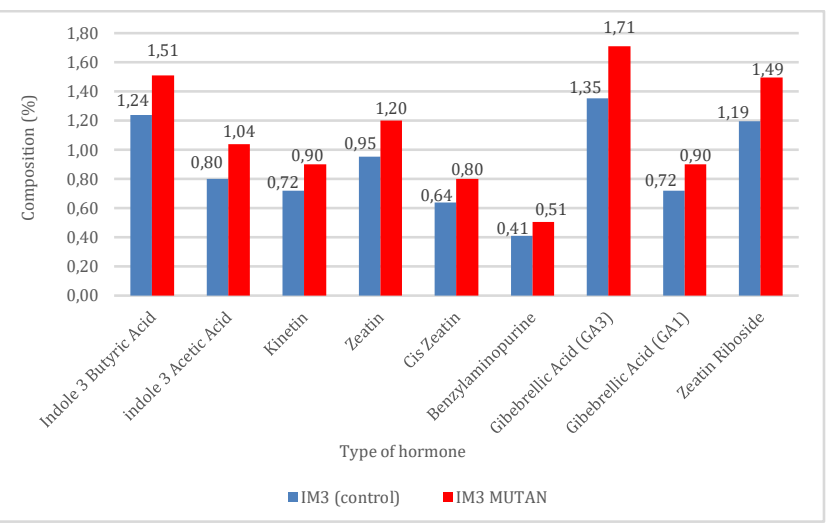

Figure 2: Results of GC-MS analysis of the composition of extracellular growth hormone: $\mathbf{I M} 3$ control and mutants-IM3 + gfp

\section{Analysis of Extracellular Metabolites: Osmoprotectant}

The result of the analysis of metabolites using GC-MS is obtained from five extracellular osmoprotectant compounds with different composition between the IM-3 control and the mutant IM-3 $+g f p$ that were grown in osmotic pressure condition $\mathrm{M} 63+0.5 \mathrm{M} \mathrm{NaCl}$ (Figure 3). There were an increase in some osmoprotectants in the mutant IM-3 $+g f p$ such as Glycine, Proline and Thiamine, but there were some that decrease such as Arabinose and Trehalose, as compared to the IM-3 control. This indicates that the insertion of gene gfp affects the synthesis of osmoprotectants to reach a new equilibrium of cell metabolism [12]. According to Serge et al. [13], Insertion of foreign gene to the cell affects the synthesis of osmoprotectant in the osmotic pressure condition. Moreover, the result of the GC-MS analysis shows that Trehalose was at the highest percentage in both IM-3 control and mutant IM- $3+g f p$, while the lowest percentage is Glycine in the mutant isolate IM- $3+g f p$ and IM- 3 control. This shows that the synthesis pathway of Trehalose is the most effective in osmotic pressure [14].

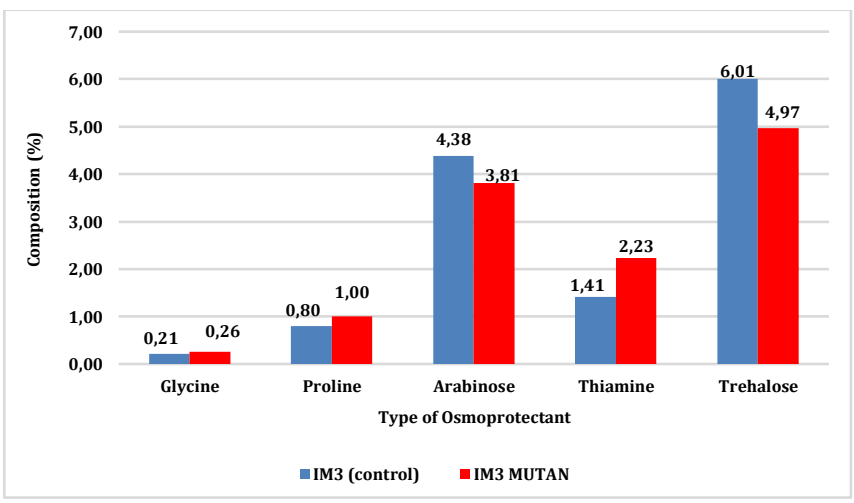

Figure 3: Results of GC-MS analysis of extracellular

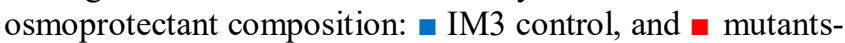
$\mathrm{IM} 3+\mathrm{gfp}$

\section{IV.CONCLUSION}

The growth pattern of IM-3 control and mutant IM-3 + gfp differ with respect to their response to osmotic pressure of $\mathrm{NaCl}$. The difference in the growth pattern is also reflected in 
the pattern of synthesis of extracellular metabolite be it in growth hormone and osmoprotectant. In the synthesis of growth hormone IBA, IAA, Kinentin, Cis Zeatin, Zeatin, Benzylaminopurine, GA3, GA1 and Zeatin Riboside there was an increase in the mutant IM-3 + $g f p$ as compared to the control. On the other hand, the synthesis of osmoprotectant compounds such as Glycine, Proline, and Thiamine increased in the mutant and decrease in the synthesis of Arabinose, , Coumestrol dan Trehalose.

\section{ACKNOWLEDGEMENTS}

Thanks to DRPM, Ristekdikti, who have funded this research. Contract no: 87/SP2H/PPM/DRPM/2018.

\section{REFERENCES}

[1]. Hallmann JA, Quadt-Hallmann A, Mahaffe WF and Kloeper JW, "Bacterial Endophytes in Agricultural Crops," Canadian Journal of Microbiology, vol. 43, pp. 895-914, 1997.

[2]. N. V. Malvanova, "Endophytic Bacteria with Plant Growth Promoting and Biocontrol Abilities," Leiden University, Rusia, 2013.

[3]. L. Persello-Cartieaux F, Nussaume and C. Robaglia, "Tales from the Underground: Molecular Plant-Rhizobacterial Interactions," Plant Cell Environ, vol. 26, pp. 189-199, 2003.

[4]. J. Hallman and G. Berg, "Dynamics of Bacterial Root Endophytes. in: Schulz B, C. Boyle, and T.Sieber (Eds). Soil Biology Mircobial Root Endophytes," SpringerVerlag, vol. 9, pp. 15-31, 2006.

[5]. Sturz A. V., B. G. Chisrtie and J. Nowak, "Bacterial Endophytes: Potential Role in Developing Sustainable Systems of Crop Production," Critical Review of Plant Science, vol. 19, pp. 1-3, 2000.

[6]. H. Ameur, M. Ghoul and J. Selvin, "Osmoprotective Effect of Some Organic Solutes on Streptomyces, Sp. MADO2 and Nocardiopsis, Sp," MADO3 growth Brazilian Journal of Microbiology, no. 42, pp. 543-553, 2011.

[7]. C. J. Bolten, P. Kiefer, F. Letisse, J. C. Portais and C. Wittmann, "Sampling for Metabolome Analysis of Microorganisms," Anal. Chem, no. 79, pp. 3843-3849, 2007.

[8]. J. S. Borner, Buchinger and D. Schomburg, "A HighThroughput Method for Microbial Metabolome Analysis Using Gas Chromatography/Mass Spectrometry," Analytical Biochemistry, no. 367, pp. 143-151, 2007.

[9]. D. G. Allison and M. A. Sattenstall, "The Influence of Green Fluorescent Protein Incorporation on Bacterial Physiology: A Note of Caution," Journal of Applied Microbiology, no. 103, pp. 318-324, 2007.

[10].K. Krause, C. Henke, T. Asiimwe, A. Ulbricht, S. Klemmer, W. Boland and E. Kothe, "Biosynthesis and Secretion of Indole-3-Acetic Acid and its Morphological Effects on Tricholoma vaccinum-Spruce Ectomycorrhiza," Journal ASM, vol. 81, no. 20, pp. 7003-7011, 2015.

[11].S. Cardinale, F. G. Tueros and M. O. A. Sommer, "GeneticMetabolic Coupling for Targeted Metabolic Engineering," Cell Reports, vol. 20, pp. 1029-1037, 2017.
[12]. S. Malonek, M. C. Rojas, P. Hedden, P. Gaskin, P. Hopkins and B. Tudzynski, "Functional Characterization of Two Cytochrome P450 Monooxygenase Genes, P450-1 and P450-4, of the Gibberellic Acid Gene Cluster Fusarium proliferatum (Gibberella fujikuroi MP-D)," Journal ASM, vol. 3, no. 71, pp. 1462-1472, 2005.

[13].M. Manzanera, J. I. Vilchez, C. Garcia-Fontana, C. Calvo and J. GOnzales-Lopez, "Genome Sequence of Leucobacter sp. 4J7B1, a Plant-Osmoprotectant Soil Microorganism," Genome Announcement, Vols. 398-205, 2015.

[14].Y. Serge, Ongagna-Yhombi and E. Fidelma Boyd, "Biosynthesis of the Osmoprotectant Ectoine, but Not Glycine Betaine, Is Critical for Survival of Osmotically Stressed Vibrio parahaemolyticus Cells," Journal ASM, vol. 16, no. 79, pp. 5083-5049, 2013. 